DIW BERLIN

Discussion Papers

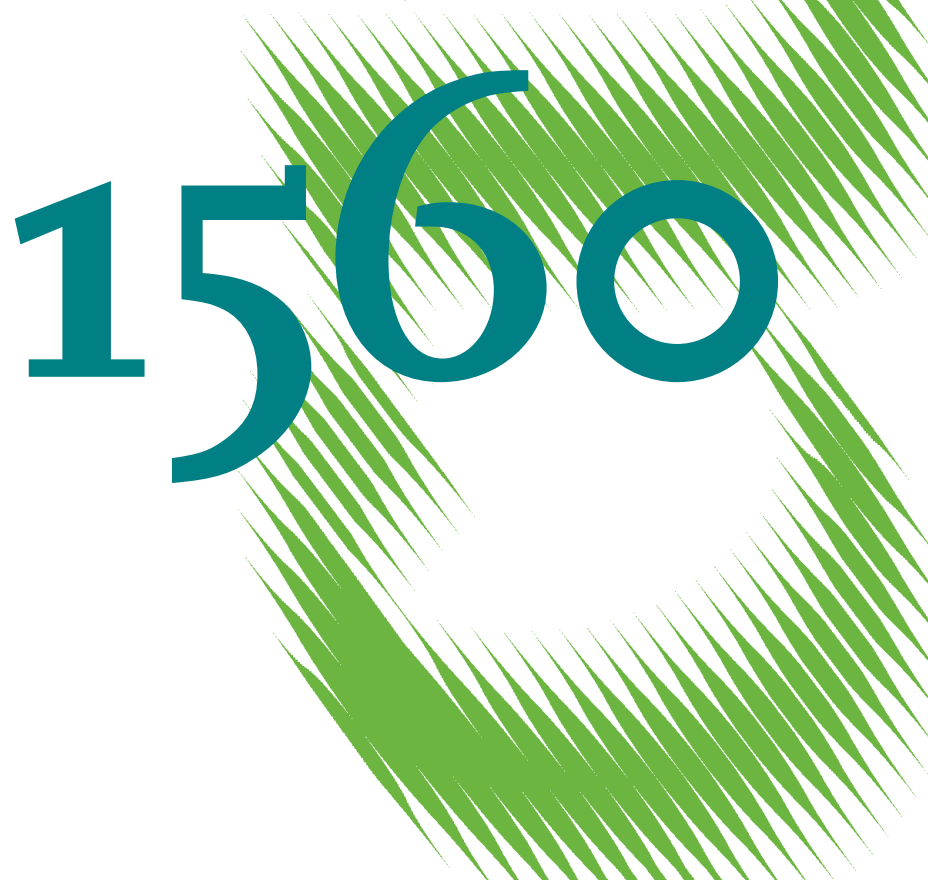

How Does Maternal Pension Wealth Affect Family Old-Age Savings in Germany? 
Opinions expressed in this paper are those of the author(s) and do not necessarily reflect views of the institute.

IMPRESSUM

(C) DIW Berlin, 2016

DIW Berlin

German Institute for Economic Research

Mohrenstr. 58

10117 Berlin

Tel. +49 (30) $89789-0$

Fax +49 (30) $89789-200$

http://www.diw.de

ISSN electronic edition 1619-4535

Papers can be downloaded free of charge from the DIW Berlin website:

http://www.diw.de/discussionpapers

Discussion Papers of DIW Berlin are indexed in RePEc and SSRN:

http://ideas.repec.org/s/diw/diwwpp.html

http://www.ssrn.com/link/DIW-Berlin-German-Inst-Econ-Res.html 


\title{
How does maternal pension wealth affect family old-age savings in Germany?*
}

\author{
Andreas Thiemann ${ }^{\dagger}$
}

March 15, 2016

\begin{abstract}
This paper examines how families adjust their private old-age savings in response to a change in individual pension wealth. The regression discontinuity approach exploits two expansions of the child care pension benefit, in 1992 and in 1999, as natural experiments. The empirical analysis is based on three waves of the Survey of Income and Expenditure (EVS): 1998, 2003 and 2008. All results indicate that families do not adjust their private old-age savings in response to the increase in their pension wealth. From a political point of view, this suggests that the increase in individual pension wealth does not crowd-out old-age private savings. Hence, child care pension benefits increase a mother's old-age income without causing negative savings effects.
\end{abstract}

Keywords: Old-age savings, pension wealth, regression discontinuity design.

JEL: D14, E21, H55.

\footnotetext{
${ }^{*}$ I am grateful to valuable comments from Peter Haan, Richard Ochmann, Michael Neumann, Patricia Gallego-Granados, Martin Beznoska, Hermann Buslei, Johannes Geyer, Daniel Kemptner, Holger Lüthen, as well as participants from several seminars. Further, I wish to thank Adam Lederer for editing the paper. Finally, I thank the Forschungsnetzwerk Alterssicherung (FNA) for the PhD scholarship. Any remaining errors are my own.

${ }^{\dagger} \mathrm{PhD}$ Candidate at the DIW Berlin Graduate Center (athiemann@diw.de).
} 



\section{Introduction}

Aging societies in many Western countries are putting financial pressure on public pension systems due to the increasing ratio of pensioners to contributors. Future pension entitlements will often be lower while the importance of old-age savings is growing. In addition, countries are implementing specific pension benefits that aim at bridging the gap in pension entitlements due to employment interruptions (OECD, 2013, 2015). In Germany, the child care pension benefit is granted to a mother ${ }^{1}$ for child-raising periods that preclude employment (Schmähl et al., 2006). Hence, this benefit intends to increase a mother's old-age income through higher pension wealth. However, if families substitute old-age savings through the child care pension benefit, then - in the worst case - mothers would not be better off at retirement than without the benefit.

This paper exploits two increases in maternal pension wealth through reforms of the German child care pension benefit as natural experiments in order to examine whether public pension wealth crowds out the old-age savings of families. The pension reforms in 1992 and in 1999 are of particular interest, as they increased the generosity of the child care pension benefit for parents of children born after December 31, 1991. Using regression discontinuity design (RDD), the paper compares the savings behavior of families with a child born in 1992 to the behavior of families with a child born in 1991. The empirical analysis is based on three waves of the Expenditure and Consumption Survey (Einkommens- und Verbrauchsstichprobe, EVS) in 1998, 2003, and 2008. Observing the savings behavior of families over this time period allows for the evaluation of whether savings adjustments occurred gradually.

The pension reform in 1992 extended the provision period from one to three years from new births and the reform in 1999 increased its generosity. Taking, for example, 2000 as the reference year, child care pension benefits increased a mother's pension payments by up to $€ 1,044$ per year if her child was born after 1991 and by up to $€ 348$ if her child was born in 1991 or earlier 2 The paper identifies the impact of this maximum annual difference of $€ 696$ per year on the old-age savings behavior of families.

Not only did the child care pension benefits increase for the parents of children born on or after January 1, 1992, but simultaneously the maximum parental leave duration increased from 18 to 36 months. Schönberg and Ludsteck (2014) show that due to the longer parental leave duration, mothers postponed their return into the labor market

\footnotetext{
${ }^{1}$ Fathers can principally be entitled to the benefit as well, however the share of fathers that receive child care pension benefits is very low.

${ }^{2}$ This paper omits the implications of the July 2014 child care pension benefit reform since the data does not cover that period. The details of the calculation are explained in Table 2 .
} 
in the short-run. If the longer absenteeism of mothers from the labor market caused families to reduce their old-age savings, then this provides a threat to the identification strategy for this paper. In order to test whether longer parental leave durations impacted on family savings, I exploit an earlier increase of parental leave in 1986. The findings suggest that families do not respond to the longer parental leave by reducing savings.

Social security wealth can mainly affect private savings through two channels, as Feldstein (1974) states: The wealth replacement effect and the induced retirement effect. According to the wealth replacement effect, the accumulation of social security wealth negatively impacts private savings. Since the accumulation of public pension wealth increases old-age income through pensions, it substitutes for household assets. Very often public pensions provide incentives for individuals to retire earlier than they would have retired without the provision of public pensions. In order to compensate for the longer period of retirement these individuals would increase their private savings while working. The net effect of social security wealth on private savings is an empirical question. In his seminal paper, Feldstein (1974) analyzed the relationship between public pension wealth and private savings. He uses aggregate time series data from the United States from 1929 through 1971, excluding the WWII years, to estimate an aggregate consumption function that includes inter alia an estimate of household security wealth. He finds that the wealth replacement effect strongly dominates the induced retirement effect. Social security wealth actually replaces 30 - 50 percent of private savings. However, these initial estimations of the displacement effect of public pension wealth on private savings might be inconsistent due to aggregation problems (Alessie et al., 2013; Feldstein and Liebman, 2002).

The seminal work by Feldstein (1974) was followed by several studies that relied on different sources of variation (e.g. Feldstein and Pellechio (1979); King and DicksMireaux (1982); Hubbard (1986); Japelli (1995)). Feldstein and Pellechio (1979) find almost a one-to-one displacement effect of private assets with respect to Social Security Wealth based survey data from 1963 from the United States. Similarly, Hubbard (1986) finds a displacement effect of public pension wealth on private savings; however the effect is substantially smaller. Japelli (1995) constructs a measure of expected pension wealth based on survey information on retirement age and replacement rates for Italy. He finds that an additional lira of pension wealth replaces between $10 \%$ and $20 \%$ of private wealth, depending on the specification. Gale (1998) shows that most previous papers, which typically regress non-pension assets inter alia on cash wages and pension wealth, underestimate the displacement effect of pension wealth. He fur- 
ther elaborates that the offset of pension wealth on non-pension assets rises with age. As a consequence he suggests an adjustment factor for pension wealth to correct for the bias.

The previous papers rely either on aggregate data, which may be subject to aggregation difficulties, or on constructed measures of pension wealth based on self-reported information. Since differences in pension wealth could just reflect different tastes for old-age savings, using direct measures of pension wealth might not always lead to consistent results. More recent papers exploit exogenous variation in pension wealth to estimate its impact on non-pension wealth. Attanasio and Rohwedder (2003) exploit three major U.K. pension reforms to estimate the impact of pension wealth on the savings rate using time series and cross-sectional variation based on the Family Expenditure Survey. They find no significant reactions to changes in the flat-rate Basic State Pension but substantial reductions of the savings rate due to changes in the earnings-related pension scheme. Similarly, Attanasio and Brugiavini (2003) estimate the impact of a large Italian pension reform in 1992 on the household savings rate in a difference-indifference setting. Based on data from the Survey on Household Income and Wealth, they find that pension wealth can be interpreted as a substitute for private financial wealth, in particular for individuals aged 35-45. Using the same data set, Bottazzi et al. (2006) emphasize that expectations about an individual's pension wealth are important for the adjustment reaction. When estimating the combined impact of the three Italian pension reforms (1992, 1995 and 1997), they find a large displacement of private wealth by perceived pension wealth, especially when workers are well informed about their pension wealth. Finally, Lachowska and Myck (2015) exploit a Polish pension reform in 1999 using the Polish Household Budget Surveys to analyze the effect of pension wealth on household savings relying on a difference-in-differences design. They find that one additional Polish zloty of pension wealth crowds out about 0.24 Polish zloty of household savings. Focusing on highly educated and older households this effect is close to minus one.

Similar to these last studies, this paper also exploits exogenous variation in pension wealth. Nevertheless, this paper differs in various aspects. While most papers exploit large variations in pension wealth, the relative importance of the increase in pension entitlements through the child care pension benefit is typically lower. Further, affected families can adjust their old-age savings over a longer time period before they enter retirement. Nevertheless, it is important to investigate if families adjust their savings even though the variation in their pension wealth is only moderate. The findings of the paper are as follows: The child care pension benefit increases a mother's pension 
wealth without crowding-out private old-age savings. Hence the child care pension benefit compensates mothers for employment interruptions by improving their old-age income.

The reminder of the paper is structured as follows: The next section describes the institutional background of the German pension system, in particular the role of child care pension benefits. Then, the identification strategy is described. Section 4 describes the data and sample construction. Section 5 covers the results. The final section concludes.

\section{Institutional background}

This section introduces the institutional background of the German Pension System, with specific background on the child care pension benefit.

The public pension plays a predominant role in the old-age income in Germany. Among retirees households, about two-thirds of household gross income originates from the public pension system ${ }^{3}$ Pension contributions are translated into so-called pension points. A pension point represents the annual pension contributions that are made by a worker who earns the average remuneration. Employees who earn a share of the average remuneration, accordingly contribute the corresponding share of a pension point. The value of the average remuneration is adjusted each year. At the verge of retirement, the amount of pension payments depends essentially on the sum of accumulated pension points over the course of working life. Pension points that are accumulated early in life are treated the same way as pension points that were accrued shortly before retirement. In 2015, a pension point represents about $€ 29$ (West Germany) of monthly pension payments (assuming the basic old-age pension without deductions). This so-called 'current pension value' is adjusted each year.

While most pension entitlements stem from contributions from employment, there are a few exceptions. One of them are pension entitlements that are granted for childraising periods that preclude employment.

Table 1 sketches the development of the child care pension benefit from 1986 through 1999, following its introduction 4 In 1986, the child care pension benefit was introduced to compensate mothers for child-raising periods that preclude employment. In this era,

\footnotetext{
${ }^{3}$ Based on households with the reference person being 65 years or older (BMAS, 2015).

${ }^{4}$ Since the data period is restricted to from 1998 to 2008, the most recent reform in 2014 is not relevant for the analysis. In 2014, the duration of the child care pension benefit was extended retrospectively from one to two years for births prior to 1992.
} 
Table 1: The Development of the German Child Care Pension Benefit 1986 - 1999

\begin{tabular}{cccc}
\hline Reform & Maximum annual benefit & Duration & Affected child births \\
\hline 1986 & $0.75 \mathrm{PP}^{\mathrm{a}}$ & 1 year & all $^{\mathrm{b}}$ \\
1992 & $0.75 \mathrm{PP}$ & 3 years & as of January 1992 \\
1999 & $\begin{array}{c}\text { 1 PP (employment } \\
\text { penalty abolished) }\end{array}$ & 3 years & $\begin{array}{c}\text { Maximum benefit was gradually } \\
\text { increased for all births. }\end{array}$ \\
\hline
\end{tabular}

a) Pension point. It represents the annual pension contributions made by a person who earns the average remuneration in a year.

b) Only mothers, born after 1921 were entitled. Mothers born before are entitled to a similar pension benefit scheme.

Source: Own illustration.

it granted 0.75 pension points per child to mothers for periods of child care 5 Since the benefit was granted for one year, it increased a mother's pension entitlements by 0.75 pension points. Translated into monetary values of 2015, 0.75 pension points increase annual pensions by about $€ 260.6$ However, pension entitlements stemming from the child care pension benefit were reduced by compulsory pension entitlements from employment if a mother was employed in that year.

The pension reform in 1992 tripled the duration of the child care pension benefit from one to three years for all births on January 1, 1992, or later. Hence, the pension wealth of affected mothers increased by up to 2.25 pension points through the child care pension benefit. In monetary terms, this is equivalent to $€ 780$ per year. Compared to births prior to the cut-off date January 1, 1992, the child care pension benefit increased by 1.5 pension points.

The pension reform in 1999 increased gradually and retrospectively the generosity of the benefit for each year from 0.75 to one pension point 7 Further, there was no longer an employment penalty if a mother became employed during periods for which the child care pension benefit was granted if the sum of pension entitlements from employment and the child care pension benefit did not exceed the pension entitlements based on the contribution ceiling. In 2015, the contribution ceiling amounts to twice the average remuneration or $€ 72,600$.

\footnotetext{
${ }^{5}$ Mothers who were born before 1921 were not entitled. However, they were entitled to a similar pension benefit.

${ }^{6}$ Assuming basic old-age retirement without deductions and West German pension values.

${ }^{7}$ The monthly value at retirement of the child care pension benefit was increased from July, 1998 to 0.85 pension points, from July, 1999 to 0.9 pension points and from July, 2000 to one pension point (§256d SGB VI).
} 
Old-age income typically stems from different sources such as the public pension fund, private pension schemes, transfers, private wealth and other sources. By increasing the monthly pension payments, the child care pension benefit lowers, ceteris paribus, the incentives for private old-age savings. Two children for instance, who are both born after 1991, would increase a mother's annual pension payments by about $€ 2,090$ - at the most - through the child care pension benefit, based on 2015 West German pension values. However, since the generosity of the child care pension benefit depends on the date of child birth, mothers face different savings incentives depending on the child's date of birth. Comparing a mother A, whose child was born in 1991, to a mother B who had a child in 1992, then the negative old-age savings incentive is much stronger for mother A, since she benefits to a smaller extend from the child care pension benefit 8 The previous example implicitly assumed that mothers do not retire earlier in response to the increase in their pension wealth. This induced retirement effect would motivate mothers to increase old-age savings to compensate for the longer period of retirement. Previous evidence suggests that the net old-age savings effect is negative, however its magnitude is an empirical question.

\section{Identification}

The paper exploits the pension reforms in 1992 and 1999 as natural experiments to identify the impact of higher individual pension wealth on family savings. Table 2 shows the positive impact of the child care pension benefit on pension entitlements of mothers by the child's year of birth (1991 or 1992) and for two different points in time. While panel (A) reports the changes in pension entitlements measured in pension points, panel (B) shows their monetary equivalence. In general, the pension entitlements of a 1992 mother increase more strongly than those of a 1991 mother. Based on the regulation of 1992, the child care pension benefit augments the annual pension payments of a mother by $€ 261$ if her child was born in 1991 and by $€ 783$ if it was born in the next calender year. The reform of the child care pension benefit in 1999, fully

\footnotetext{
${ }^{8}$ It has to be mentioned that retirees can only take advantage of the child care pension benefit if their pension level exceeds the one that corresponds to the minimum pension. Otherwise, their pension payments would be increased in order to reach the minimum pension level. Then, the child care pension benefit would have no impact on the level of pension payments. However, the share of retirees who receive the minimum pension is very low. In 2011, the share of persons aged 65 or older who receive the minimum pension is $2.6 \%$ (Duschek and Lemmer, 2013). Further, to take advantage of the child care pension benefit a mother has to fulfill the general requirements of five years of contributions for being entitled to the old-age pension.
} 
Table 2: Identification design

\begin{tabular}{clc}
\hline Child born in & $\begin{array}{c}\text { Variation of a mother's pension entitlements due to } \\
\text { changes in the child care pension benefit }\end{array}$ \\
& in 1992 (January) & in 2000 (July) \\
\hline & (A) in pension points (PP) \\
1991 & +0.75 & +1.0 \\
1992 & +2.25 & +3.0 \\
& (B) in annual pension payments ${ }^{a}$ \\
1991 & $+€ 261$ & $+€ 348$ \\
1992 & $+€ 783$ & $+€ 1044$ \\
\hline
\end{tabular}

Note: The table reports the maximum change of a mother's pension entitlements by a child's year of birth (1991 or 1992) that is due to changes in the child care pension benefit.

a) Based on West German values of 2015 (1 PP $€ € 29 /$ month), assuming that a mother enters retirement in 2015 and receives old-age pension without deductions. In this calculation, I ignore the reform of the child care pension benefit in 2014 because this it is not covered by the available time horizon of the data I use. Source: Various German Federal Laws; Own illustration.

phased-in in July 2000, further strengthens the preferential treatment of 1992 mothers. After July 2000 the maximum difference in pension entitlements through child care pension benefits between 1992 mothers and 1991 mothers is $€ 696$ per annum. Can the impact of individual pension wealth on family saving be identified by comparing the savings behavior of 1992 mothers and 1991 mothers? Let us refer to 1991 mothers as the control group and to 1992 mothers as the treatment group. If mothers are randomly assigned into the two groups and if the only systematic difference is the higher generosity of the child care pension benefit in the treatment group, then we can identify the impact of pension wealth on family savings 9

First, the assignment of a family either in the control or in the treatment group is determined by the child's year of birth. The increase in the child care pension benefit - granted to parents of babies born in January 1992 or later - provides an incentive for parents to have a child in 1992 instead of 1991. Since the German Parliament had already adopted the Pension Reform Act 1992 in December 1989, parents could theoretically have decided to have a child in 1992 instead of 1991. However, the ex-

\footnotetext{
${ }^{9}$ The identification strategy of this paper follows closely Thiemann (2015), in which I investigate the impact of the child care pension benefits on maternal employment in the short- and medium run.
} 
act timing of conception cannot perfectly be controlled by the parents. The duration of pregnancy follows a normal distribution of 40 weeks and a standard deviation of two weeks (Ekberg et al., 2013, p. 135). Nevertheless, the literature documents some shifting of births by parents for a few public benefits reforms that are based on a specific cut-off date (Neugart and Ohlsson, 2013; Gans and Leigh, 2009; Tamm, 2012). Whether child births might have been postponed and shifted from 1991 into 1992 was already investigated by Dustmann and Schönberg (2008, Appendix A). However, they do not find any evidence that child births were shifted around the turn of the year. Further, in Thiemann (2015) I investigate the birth patterns around the turn of the year 1991/92 and compare the total number of births with the two subsequent years based on the birth statistics for West Germany 10 , without finding a strategic timing of birth behavior.

Second, a systematic difference could arise from the fact that a child born in 1991 is on average one year older than a child who was born in 1992. Ideally, one would compare parents who had a child shortly around the cut-off date 1/1/1992, e.g. based on child births in December 1991 and January 1992. However, the data set only provides information about the year of birth 11 Therefore, the empirical model controls factors that are different across both groups as a result of this age difference, namely the parent's age and employment status. To cross-validate the assumption of random assignment, I perform a standard test in empirical work and compare the distribution of observable characteristics across both groups (Lee and Lemieux, 2010). The results do not provide evidence for a non-random selection (c.f. Table 3).

Third, is the more generous child care pension benefit the only systematic difference across treatment and control groups? Regarding institutional differences, other pension reforms were dependent on the mother's and not the child's date of birth. Therefore they identically affected mothers in the treatment and control groups. However, in 1992 not only the child-care pension benefit, but also parental leave was extended in the same discontinuous way. The reform extended the parental leave duration from 18 to 36 months for all newborns from January 1, 1992. The longer parental leave period for 1992 mothers is a threat to the identification strategy if old-age savings behavior in the treatment group was affected by the policy change. Schönberg and Ludsteck (2014) document that mothers substantially postponed the return into the labor market after child birth in the short-run, but not in the long-run. Since mothers in the control group tend to return earlier into employment than mothers in the treatment group, they could accumulate more pension entitlements through compul-

\footnotetext{
${ }^{10}$ The date does not contain births for Saarland.

${ }^{11}$ The data is explained in detail in section 4
} 
sory pension contributions in this period. These additional pension entitlements would then reduce the positive savings incentive for 1991 mothers relative to 1992 mothers. However, this theoretical savings effect is likely to be rather small. First, mothers who re-entered employment at that time were very likely to work part-time (see e.g. Geisler and Kreyenfeld (2005)) and on average the amount of additional pension points they accrued relative to the treatment group would rather have been very small. Nevertheless, to assess the impact of the parental leave duration on old-age savings, I exploit a previous parental leave extension in 1986 to estimate its impact on savings. Despite the fact that the two parental leave extensions, in 1992 and in 1986, are not entirely comparable, this exercise provides evidence that the impact of the parental leave extension on family savings is rather low (c.f. Section 5.4.1).

Further, the child care pension benefit could have had an indirect effect on old-age savings via employment. The more generous child care pension benefit for 1992 mothers provides an incentive for mothers to return later into employment due to the higher pension wealth. If 1991 mothers return earlier into employment and if employed mothers are more likely to contribute a higher fraction of income to family savings, then the identification strategy of this paper could not distinguish the direct impact of the child care pension benefit from its indirect effect through employment on family oldage savings. In Thiemann (2015) I study how child care pension benefits affect the employment decision of mothers in the short- and the medium-run. However, I do not find empirical support for the presumption that mothers return later into employment as a results of the more generous child care pension benefit.

The empirical method that underlies the identification strategy of this paper is the regression discontinuity design. If individuals cannot precisely control the assignment rule into the control and the treatment group, then this treatment variation is "as good as randomized." As a result, the regression discontinuity design (RDD), if applicable, is often considered as potentially more credible than other research designs that exploit natural experiments (Lee and Lemieux, 2010, p. 282) and hence it is not surprising that it is applied in various economic and non-economic studies 12

The econometric model that investigates the impact of pension wealth on old-age

\footnotetext{
${ }^{12}$ Thistlethwaite and Campbell $(1960)$ introduced the method to investigate the impact of merit awards on future academic outcomes. Angrist and Lavy (1999) rely on the regression discontinuity design when they investigate how class size influences the test scores of students in Israel. Black (1999) studies how much parents are willing to pay in order to send their children into better schools. An overview of applications of the regression discontinuity design in economics is provided by Lee and Lemieux (2010).
} 
savings is specified in the following way:

$$
S V_{i t}=\beta_{0}+\beta_{1} \text { Treat }_{i}+\beta_{2} 2003_{t}+\beta_{3} 2008_{t}+\sum_{s} \gamma_{s} \text { mage }_{s i}+X_{i}^{\prime} \delta+\epsilon_{i t}
$$

For the dependent savings variables $S V$, I rely on flow and stock information: Savings relative to gross income, savings relative to net income, and the stock of net wealth. For each concept, the model is estimated separately. $i$ indicates the family and $t$ determines the cross-section to which the family belongs to $(1998,2003$ or 2008). Treat equals one if a family had a child in 1992, zero if their child was born in 1991. 2003 and 2008 are dummy variables that capture the effect of being interviewed in a particular year, where 1998 is the baseline category. $X$ is a vector of control variables: Family size, father's age, federal states, education of each parent, the binary employment status of each parent and the quarter of interview and $\epsilon$ captures the error term. Finally, the indicators for the age of a mother control non-parametrically for the length of her adjustment horizon (the time until retirement). When a mother experiences a change of her pension wealth, the savings reaction tends to be the smaller the longer the period in which savings can be adjusted and the further away she is from the expected retirement entry date. Hence, the savings response of a family with a young mother is usually, ceteris paribus, smaller than the response of a family with an older mother, based on the same variation in pension wealth (Gale, 1998). An alternative specification also includes interaction terms to control for the differential impact of being a 1992 mother in different years:

$$
\begin{array}{r}
S V_{i t}=\alpha_{0}+\alpha_{1} \text { Treat }_{i}+\alpha_{2} 2003_{t}+\alpha_{3} 2008_{t}+\alpha_{4} \text { Treat }_{i} * 2003_{t} \\
+\alpha_{5} \text { Treat }_{i} * 2008_{t}+X_{i}^{\prime} \lambda+\sum_{s} \xi_{s} \text { mage }_{s i}+\tilde{\epsilon}_{i t},
\end{array}
$$

where the additional interaction terms $2003 *$ Treat and $2008 *$ Treat capture the differential impact of a 1992 mother in 2003 or 2008 relative to a 1992 mother in 1998. The structure of the data does not allow for separating the effects for the two reforms of the child-care pension benefit in 1992 and 1999. Therefore, I interpret the two reforms as a "reform package" that favored 1992 mothers.

\section{Data}

The empirical analysis relies on the Income and Consumption Survey (Einkommensund Verbrauchsstichprobe, EVS). The EVS is based on a stratified quota sample of about 0.2 percent of private households and repeated every five years. In 2008, about 
55,000 to 59,000 households participated, depending on the section of the survey. For a thorough description of the EVS, I refer to Statistisches Bundesamt (2013). In addition to socio-demographic information about household members, the data offers detailed information about income and expenditure and wealth component:13 of German households. The EVS only covers households whose net earnings do not exceed $€ 18,000$ per month. However, this limitation is of minor concern as the share of households earning more than $€ 18,000$ per month is very smal[ ${ }^{14}$ and these households are most likely hardly affected by the child care pension benefit because the increase in pension wealth is very small relative to their monthly income. While the EVS contains the year of birth of household members, it does not inform about the precise month of birth. Therefore, the assignment of families into the control and treatment group must be made based on the child's year of birth. I rely on the scientific use files of the EVS: a $80 \%$ sub-sample, which provides information for more than 42,000 households per wave (Statistisches Bundesamt, 2013, 2005, 2002). I use three consecutive waves from 1998, 2003, and 2008. To harmonize them, the monetary values of 1998 are converted from Deutsch Mark into Euro using the official exchange rate of 1.95583 Deutsch Mark per Euro. Further, monetary values from 1998 and 2008 are deflated to prices of 2003 based on the Consumer Price Index ${ }^{15}$ In this paper, I define savings as net expenditures for the wealth accumulation and relate this measure to net income and to gross income. Net wealth is defined as the sum of real estate property and financial wealth. Further, the net wealth variable is divided by 1,000 for a more convenient representation. ${ }^{16}$ Parents who had a child, either in 1991 or 1992, are selected into the sample, which is the case for 8,854 families. If parents had more than one child in 1991 or in 1992, they are excluded because pension entitlements of these mothers increased more because child care pension benefits are granted per child. I also exclude parents who had a child in 1991 and another one in 1992 because they had to be assigned into the

\footnotetext{
${ }^{13}$ While the EVS informs about real estate as well as financial wealth components, it does not provide sufficient information about business wealth.

${ }^{14}$ Based on the GSOEP (German Socio-Economic Panel) data, the share of households with a net income of at least $€ 18,000$ is less than $1 \%$ in 2008. For a description of the data, I refer to Wagner et al. (2007)

${ }^{15}$ I am grateful to Richard Ochmann for helpful code that facilitated the harmonization of the three waves of the EVS.

${ }^{16}$ Savings $=$ accumulation of real assets - liquidation of real assets + accumulation of financial assets - liquidation of financial assets + repayment of loans - take-up of new loans. Households with implausible values of lower than -0.5 and higher than 0.5 of the savings quota are excluded. The financial wealth component in 1998 had to be adjusted for flows to guarantee comparability to 2003 and 2008. In contrast to the EVS 2003 and 2008, where financial wealth was recorded on January 1, in 1998 the it was reported for the end of the interview quarter.
} 
treatment and control groups. In addition, families in which a mother is either selfemployed, a freelancer, a civil servant or already retired are not considered since these mothers are less likely to be affected by the child care pension benefit. In Germany, many of these professions have separate pension schemes. Further, I only consider West German households since after re-unification in 1990, East Germany experienced a dramatic drop in fertility that is likely to have been selective (Chevalier and Olivier, 2015). Finally, I focus on couple families with no other household members than children. Hence, all households that are included are families where both parents are part of the same household ${ }^{17}$ The remaining final sample size is 5,450 families.

\section{Results}

Next, this section discusses the descriptive results and the findings from estimating the econometric model.

\subsection{Descriptive results}

Table 3 compares the different savings/wealth concepts and socio-demographic characteristics for the treatment and the control groups. Both savings rates - relative to gross income and relative to net income - are similar across treatment and control groups. On average, about 13\% (10\%) of household net income (gross income) is declared as savings. This provides some first indication that families in the treatment group tend not to substitute old-age savings with public pension wealth. Nevertheless, families in the treatment group hold more net wealth on average. But parents in the treatment group are - due to construction - about a year younger than in the control group. Further, the share of employed mothers seems to be slightly higher in the treatment group. The remaining socio-demographic characteristics are very similar across treatment and control groups. Most fathers are employed, with about one third holding a university degree. The corresponding share among women is $17 \%$. Finally, families have, on average, about two children. To sum up, the comparison of the socio-demographic characteristics across treatment and control group suggests that families of 1991 mothers are not systematically different in observable characteristics from families of 1992 mothers.

\footnotetext{
${ }^{17}$ In a further step, the paper estimates the savings responses for single mothers (section 5.3 .
} 
Table 3: Sample characteristics by Treatment and Control groups

\begin{tabular}{lrrrrl} 
& \multicolumn{2}{c}{ Control } & Treatment & Difference \\
\hline Variable & Mean & SD & Mean & SD & t-statistic \\
\hline Savings and net wealth & & & & & \\
Savings/gross income & 0.105 & 0.128 & 0.103 & 0.127 & 0.498 \\
Savings/net income & 0.132 & 0.158 & 0.130 & 0.159 & 0.533 \\
Net wealth & 186.7 & 211.5 & 170.5 & 179.3 & $3.046^{* * *}$ \\
Socio-demographics & & & & & \\
Mother's age & 40.08 & 5.600 & 39.23 & 5.665 & $5.533^{* * * *}$ \\
Father's age & 42.93 & 6.297 & 41.99 & 6.693 & $5.362^{* * *}$ \\
Mother employed & 0.442 & 0.497 & 0.469 & 0.499 & $-1.958^{*}$ \\
Father employed & 0.943 & 0.232 & 0.945 & 0.229 & -0.304 \\
University degree (mother) & 0.169 & 0.375 & 0.167 & 0.373 & 0.201 \\
University degree (father) & 0.344 & 0.475 & 0.336 & 0.472 & 0.598 \\
Family size & 4.224 & 0.636 & 4.214 & 0.651 & 0.570 \\
\hline Group size & 2759 & 2691 & \\
\hline
\end{tabular}

Notes: The sample is based on West German couple families who had a child either in 1991 (Control group) or in 1992 (Treatment group). Net wealth is measured in $€ 100,000$ s. $* / * * / * * *$ Statistically significant at the $10 \% / 5 \% / 1 \%$-level.

Data source: Income and Expenditure Survey (EVS) 1998, 2003 and 2008.

\subsection{Main results}

Next, Table 4 provides an econometric assessment of the impact of pension wealth on old-age savings, exploiting the increase of the child care pension benefit. While in the left panel of the table savings is related to net income, in the right panel the savings rate is based on gross income. In the following, 'Treatment' is defined as the impact of being in the treatment group, i.e. families with a child birth in 1992, on a family's old-age savings. 


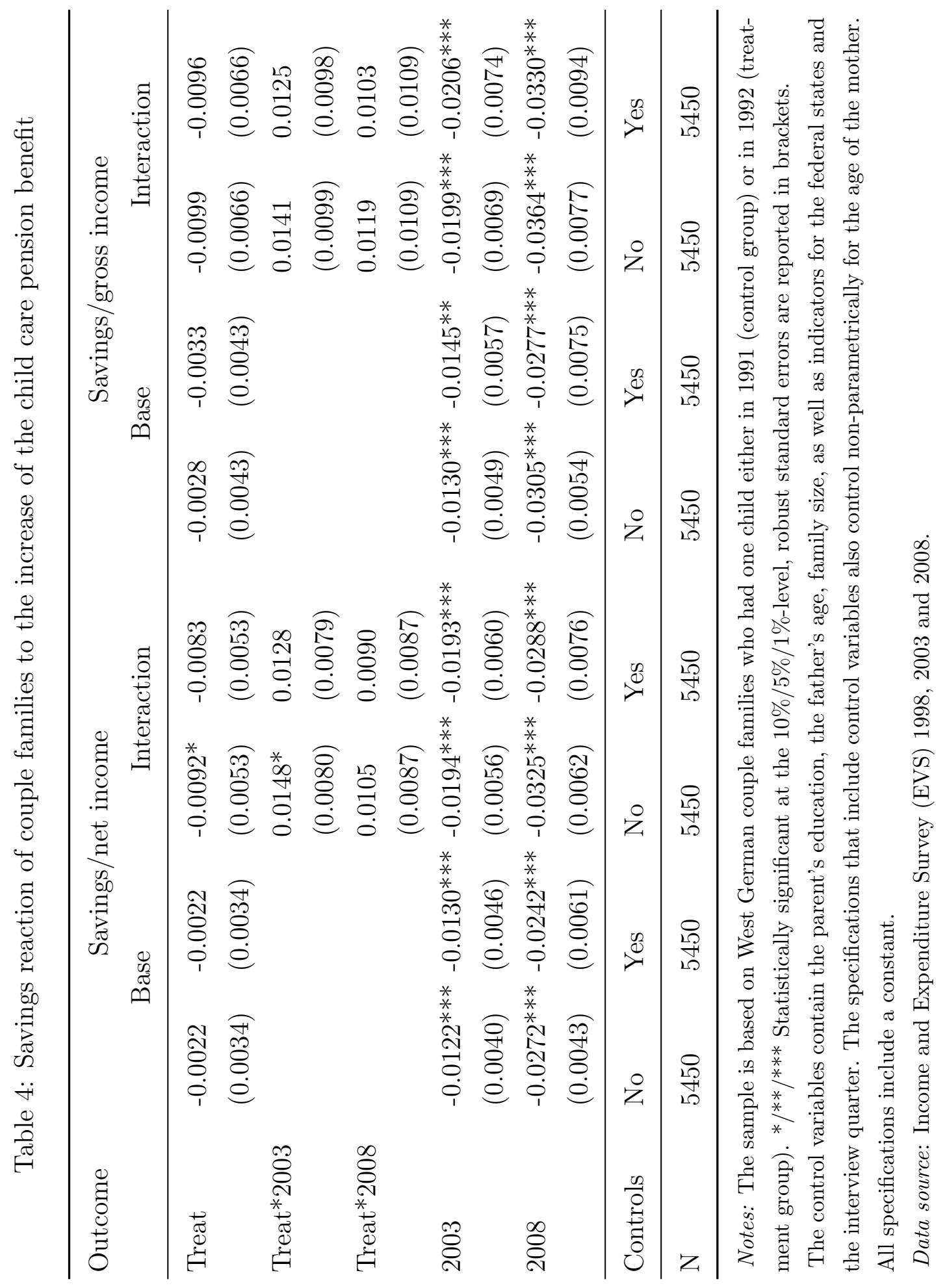


The results of the OLS estimation of equation 1 are displayed in the 'Base' columns and the results of the OLS estimation of equation 2 are shown in the 'Interaction' columns. Each first column provides an estimate without control variables, apart from year indicators. The specifications with controls include the parent's education, the father's age, the family size, as well as indicators for the federal states and for the quarter of interview. Further they control non-parametrically for a mother's age. First, we focus on the the left panel that relates family savings to net income. In the Base model, the point estimate of the treatment effect is very small. Taking it at its face value, the increase in pension wealth - due to the more generous child care pension benefit - would reduce the savings rate by 0.22 percentage points. While the direction of the effect is in line with our expectations, the magnitude of the effect is literally zero. Furthermore, it is not statistically significant. The inclusion of control variables leaves the estimated effect unchanged. Considering the estimated treatment effect based on the interaction model, the estimated effect is negative with - 0.92 percentage points and only weakly statistically significant. However, controlling for socio-economic characteristics renders the effect statistically insignificant. The positive point estimates of the interaction terms suggest that families with 1992 mothers tend to save more in 2003 and 2008 than in 1998. However, again after including controls in the model, this relationship vanishes. When looking at the right panel, which shows the estimates based on the savings rate relative to gross income, the findings are very similar to model that uses the savings rate relative to net income. Sign and magnitude of the effect estimates are almost identical and in none of the four specifications, the estimated relationship appears to be statistically significant. Considering all results together, it suggests that overall the the more generous individual child care pension benefit had no impact on family savings decisions.

Next, Table 5 focuses on the impact of the treatment on the stock of net wealth. The OLS results are shown for Equation 1 and 2, with and without the inclusion of controls. In the first column, the base model predicts a very strong significant negative impact of treatment on the stock of net wealth. Accordingly, being in the treatment group would reduce net wealth substantially by about $€ 15,000$. Even though, this negative relationship is in line with our expectations, the effect size is very large. However, after adding controls the magnitude of the effect becomes much smaller and it turns insignificant. Since, parents in the control group are on average about one year older, it seems quite plausible that their stock of wealth is higher 18 However, this result

\footnotetext{
${ }^{18}$ Figure 1 and Figure 2 (in the appendix) show the average net wealth by the age of a parent. The graphs show that net wealth increases by a parent's age, at least until the age of 50. After that age level the results become fuzzy due to the smaller number of observations.
} 
Table 5: The impact of of the increase in child care pension benefits on the net wealth of couple families

\begin{tabular}{lllll}
\hline Outcome & \multicolumn{3}{c}{ Net wealth } \\
& \multicolumn{3}{c}{ Interaction } \\
\hline Treat & $-15.0857^{* * *}-4.7010$ & $-15.0017^{* *}$ & 0.3357 \\
& $(5.2562)$ & $(4.8711)$ & $(6.0659)$ & $(5.5976)$ \\
Treat*2003 & & -1.7503 & -9.7316 \\
& & $(12.8910)$ & $(12.4216)$ \\
Treat*2008 & & 2.0994 & -8.6956 \\
& & & $(13.2035)$ & $(12.5004)$ \\
2003 & $43.6087^{* * *}$ & -5.6541 & $44.4512^{* * *}$ & -0.8899 \\
& $(6.4734)$ & $(6.3606)$ & $(9.9502)$ & $(9.4174)$ \\
2008 & $41.0248^{* * * *}$ & $-48.8457^{* * *}$ & $40.0106^{* * *}$ & $-44.4733^{* * *}$ \\
& $(6.6105)$ & $(9.7172)$ & $(9.6078)$ & $(11.8039)$ \\
\hline Controls & No & Yes & No & Yes \\
\hline N & 5450 & 5450 & 5450 & 5450 \\
\hline
\end{tabular}

Notes: The sample is based on West German couple families who had one child either in 1991 (control group) or in 1992 (treatment group). */**/*** Statistically significant at the $10 \% / 5 \% / 1 \%$-level, robust standard errors are reported in brackets.

The control variables contain the parent's education, the father's age, family size, as well as indicators for the federal states and the interview quarter. The specifications that include control variables also control nonparametrically for the age of the mother. All specifications include a constant.

Data source: Income and Expenditure Survey (EVS) 1998, 2003, and 2008.

stresses the importance of including the age of parents as regressors to account for this age difference between the two groups. The interaction model confirms these findings. Likewise, the interaction model without controls finds a strong negative and significant effect that vanishes after including controls into the model.

Considered together, the findings suggest that the negative savings incentives, implied by the more generous child care pension benefit, did not influence the savings behavior of affected parents.

What could be potential explanations for the lack of finding a savings response of parents? Parents could have a strong discount factor or a short decision-making horizon. 
For these parents the magnitude of the beneficial provision of the child care pension benefit would have been too small, since they value current income more strongly than future income. Alternatively, they might not have considered the impact of today's decision on future income. To test whether the relative importance of child care pension benefits in old-age income matters, one should divide the sample according to the level of the expected old-age income of a family and repeat the analysis. The maximum gain from the more generous child care pension benefit provision is generally not dependent on future old-age income. Hence, the relative importance of the child care pension benefits for old-age income diminishes with increasing expected old-age income. Since the data does not provide information about future old-age income, I split the sample according to net income and net wealth, which seems to be a good proxy and repeat the analysis.

\subsection{Heterogeneous effects}

Table 6 shows the estimation results for the interaction model (equation 2), including controls, by quartiles of net income and by quartiles of net wealth. In the upper part, the outcome is the savings rate, based on net income 19 The lower part focuses on the specification where the outcome is replaced by net wealth. From the comparison of the treatment effect by quartiles of family net income and net wealth, we can infer how the treatment effect evolves along the net income and wealth quartiles. First, we focus on the upper part of the table. Comparing the estimated treatment effect by quartiles of net income shows that the effect is not statistical significantly different from zero in any of the four quartiles. Apart from the second quartile, the point estimates are relatively small. However, the high standard errors indicate the large statistical uncertainty. Next, the sample is distinguished by the four different net wealth quartiles. Again, in three of the four quartiles the treatment effects are relatively small and statistically insignificant. Only for families whose net wealth falls in the second quartile is the treatment estimate negative and weakly significant. Accordingly, the more generous child care pension benefit lowers their savings rate moderately by about three percentage points. Now, we focus on the lower panel of the table, where the outcome is net wealth. Again, comparing the treatment effect by net income quartiles does not provide a clear pattern. All four separate treatment estimates are statistically insignificant. Repeating the exercise based on the net wealth quartiles shows that apart from the estimated treatment effect in the first quarter, which is only weakly statistically significant, all estimates are statistically insignificant.

\footnotetext{
${ }^{19}$ The results for the savings rate, based on gross income, are very similar and available upon request.
} 
Table 6: Het: Savings reaction of couple families to the increase of the child care pension benefit by hhnetinc and net wealth quartiles

\begin{tabular}{|c|c|c|c|c|c|c|c|c|}
\hline \multirow{3}{*}{$\begin{array}{l}\text { Outcome } \\
\text { Sub-sample }\end{array}$} & \multicolumn{8}{|c|}{ Savings/net income } \\
\hline & \multicolumn{4}{|c|}{ Net income quartiles } & \multicolumn{4}{|c|}{ Net wealth quartiles } \\
\hline & $Q 1$ & $Q^{2}$ & Q3 & Q4 & $Q 1$ & Q2 & Q3 & Q4 \\
\hline \multirow[t]{2}{*}{ Treat } & 0.0039 & -0.0182 & -0.0068 & -0.0060 & 0.0050 & $-0.0324^{* *}$ & -0.0069 & 0.0003 \\
\hline & $(0.0116)$ & $(0.0126)$ & $(0.0134)$ & $(0.0151)$ & $(0.0116)$ & $(0.0134)$ & $(0.0129)$ & $(0.0155)$ \\
\hline \multirow[t]{2}{*}{ Treat*2003 } & -0.0187 & 0.0203 & 0.0163 & 0.0019 & -0.0039 & 0.0284 & 0.0245 & -0.0111 \\
\hline & $(0.0208)$ & $(0.0182)$ & $(0.0192)$ & $(0.0212)$ & $(0.0192)$ & $(0.0194)$ & $(0.0197)$ & $(0.0216)$ \\
\hline \multirow[t]{2}{*}{ Treat*2008 } & 0.0284 & 0.0127 & 0.0042 & -0.0044 & 0.0095 & $0.0399^{*}$ & 0.0108 & -0.0223 \\
\hline & $(0.0216)$ & $(0.0208)$ & $(0.0206)$ & $(0.0243)$ & $(0.0206)$ & $(0.0213)$ & $(0.0225)$ & $(0.0245)$ \\
\hline $\mathrm{N}$ & 1362 & 1363 & 1363 & 1362 & 1362 & 1363 & 1363 & 1362 \\
\hline Outcome & \multicolumn{8}{|c|}{ Net wealth } \\
\hline \multirow{2}{*}{ Sub-sample } & \multicolumn{4}{|c|}{ Net income quartiles } & \multicolumn{4}{|c|}{ Net wealth quartiles } \\
\hline & $Q 1$ & $Q^{2}$ & Q3 & Q4 & $Q 1$ & $Q^{2}$ & Q3 & Q4 \\
\hline \multirow[t]{2}{*}{ Treat } & 13.0190 & 1.3925 & -4.5665 & 8.5361 & $-2.9894^{*}$ & -0.4093 & -0.6284 & 23.0658 \\
\hline & $(8.1169)$ & $(9.5827)$ & $(11.8541)$ & $(15.0206)$ & $(1.6667)$ & $(2.3866)$ & $(2.5058)$ & $(14.4930)$ \\
\hline \multirow[t]{2}{*}{ Treat*2003 } & -18.4780 & 9.1969 & -18.3571 & -41.9489 & 2.0675 & 3.7293 & -1.8408 & -42.0127 \\
\hline & $(15.3781)$ & $(20.9549)$ & $(26.8941)$ & $(29.3954)$ & $(4.5805)$ & $(3.8376)$ & $(4.0998)$ & $(29.5804)$ \\
\hline \multirow[t]{2}{*}{ Treat*2008 } & -5.5279 & 12.4265 & -22.0639 & -27.9454 & -1.3727 & -2.5288 & 7.0925 & $-62.9179^{* *}$ \\
\hline & $(25.5685)$ & $(21.6262)$ & $(22.0902)$ & $(29.2458)$ & $(5.3714)$ & $(4.3302)$ & $(4.4134)$ & $(28.9811)$ \\
\hline $\mathrm{N}$ & 1362 & 1363 & 1363 & 1362 & 1362 & 1363 & 1363 & 1362 \\
\hline
\end{tabular}

Notes: The sample is based on West German couple families who had one child either in 1991 (control group) or in 1992 (treatment group). Net wealth is measured in $€ 100,000$ s. * $/^{* *} / * * *$ Statistically significant at the $10 \% / 5 \% / 1 \%$-level, robust standard errors are reported in brackets.

All specifications are based on the model that is specified by equation 2, including control variables. They are the parent's education, the father's age, family size, as well as the federal states and the interview quarter. The specifications that include control variables also control non-parametrically for the age of the mother. All specifications include a constant.

Data source: Income and Expenditure Survey (EVS) 1998, 2003, and 2008.

Considered together, the findings suggest that families do not react differently to the more generous child care pension benefit, depending neither on their position in the net income nor net wealth distribution. Only families in the treatment group who are in the second net wealth quartile tend to save less in response to the more generous child care pension benefit.

So far, the sample consists of families in which both parents were present. Next, I focus on a subgroup of the population that might have been affected in particular by 
the more generous child care pension benefit provision. In contrast to couple families, the old-age income of single mothers is based on their own pension wealth and old-age savings. Single mothers cannot pool their old-age income with a partner - if they remain single - and hence a change in their pension wealth might have a stronger impact on their savings behavior. Further, single mothers generally posses less wealth than couple families (see Table 3 and Table 15 ). Therefore, they belong to a more vulnerable subgroup of the population.

Table 15 in the appendix compares the sample characteristics by the correspond-

Table 7: Savings reaction of single mothers to the increase of the child care pension benefit

\begin{tabular}{lcccccccc}
\hline \multirow{2}{*}{$\begin{array}{l}\text { Outcome } \\
\text { Model }\end{array}$} & \multicolumn{3}{c}{ Savings/net income } & \multicolumn{3}{c}{ Net wealth } \\
\hline Treat & -0.0026 & -0.0025 & -0.0262 & -0.0302 & -1.7760 & 0.4547 & -5.0505 & -2.6365 \\
& $(0.0119)$ & $(0.0115)$ & $(0.0190)$ & $(0.0193)$ & $(8.0746)$ & $(7.9678)$ & $(14.9830)$ & $(14.8671)$ \\
Treat*2003 & & & 0.0160 & 0.0166 & & & 7.5054 & 0.8109 \\
& & & $(0.0298)$ & $(0.0303)$ & & & $(19.8736)$ & $(19.8008)$ \\
Treat*2008 & & & $0.0532^{*}$ & $0.0638^{* *}$ & & & 2.4009 & 8.0960 \\
& & & $(0.0275)$ & $(0.0273)$ & & & $(20.4317)$ & $(20.0115)$ \\
2003 & -0.0084 & -0.0138 & -0.0144 & -0.0201 & 8.2954 & -6.1484 & 4.5009 & -6.2972 \\
& $(0.0148)$ & $(0.0168)$ & $(0.0218)$ & $(0.0226)$ & $(10.0793)$ & $(11.2459)$ & $(14.3041)$ & $(15.7098)$ \\
2008 & -0.0157 & -0.0098 & $-0.0396^{* *}$ & $-0.0397^{*}$ & 6.6152 & $-23.4751^{*}$ & 5.5824 & -27.3215 \\
& $(0.0138)$ & $(0.0197)$ & $(0.0193)$ & $(0.0227)$ & $(10.3510)$ & $(12.9394)$ & $(14.9845)$ & $(17.2322)$ \\
\hline \multirow{2}{*}{ Controls } & \multirow{2}{*}{ No } & Yes & No & Yes & No & Yes & No & Yes \\
\hline N & 666 & 666 & 666 & 666 & 666 & 666 & 666 & 666 \\
\hline
\end{tabular}

Notes: The sample is based on West-German single mothers who had one child either in 1991 (control group) or in 1992 (treatment group). Net wealth is measured in $€ 100,000$ s. $* / * * * * *$ Statistically significant at the $10 \% / 5 \% / 1 \%$-level, robust standard errors are reported in brackets. The control variables contain the mother's education, the mother's employment status, family size, as well as indicators for the federal states and the interview quarter. The specifications that include control variables also control non-parametrically for the age of the mother. All specifications include a constant.

Data source: Income and Expenditure Survey (EVS) 1998, 2003, and 2008.

ing treatment and control groups that are constructed analogously to couple families. Mothers in the treatment group are not substantially different from mothers in the control group. Solely, 1991 mothers tend to be more likely to be in employment compared to 1992 mothers. However, for the purpose of this analysis the two groups seem to be comparable. Table 7 shows the treatment effect for single mothers. In the left 
part of the table, the outcome is defined as savings/net income ${ }^{20}$ In the right part, the outcome is defined as net wealth. In contrast to the previous econometric models, the control variables that are included are the mother's education, the mother's employment status, family size, the federal states and the the interview quarter. First, we focus on the left panel that relates family savings to net income. In the Base model, the estimated impact of being in the treatment group is negative and very small. Taking the point estimate at its face value, the increase in pension wealth - due to the more generous child care pension benefit - would reduce the savings rate by 0.26 percentage points. However, this relationship is not statistically significant. The inclusion of control variables does not affect the estimated effect. Considering the estimated impact based on the interaction model, the estimated effect is - 2.6 to -3 percentage points, but not statistically significant. The right panel shows the estimated treatment effect, when the outcome is net wealth. The first column of the base model predicts a moderate negative impact on net wealth. However, after including controls, the effect estimate turns even positive and its magnitude becomes much smaller. The same pattern is true for the interaction model. After including controls, the magnitude of the point estimate shrinks substantially. However, all point estimates are statistically insignificant, reflecting the statistical uncertainty due to the smaller sample size.

Considering the findings for single mothers together, no reaction to the increase in their pension wealth due to the more generous child care pension benefit can be identified, neither for the savings rate nor for their stock of net wealth.

\footnotetext{
${ }^{20}$ Specifying the savings rate as savings relative to gross income leads to similar results.
} 


\subsection{Sensitivity checks}

This section tests the sensitivity of the empirical findings.

\subsubsection{Parental Leave and family savings}

As previously described, the parental leave extension that was introduced in 1992 for newborns - similar to the increase in the generosity of the child care pension benefit imposes a threat to the identification strategy if families adjust their savings as a result of longer parental leave. To assess the potential impact of parental leave on savings, I exploit the parental leave expansion in 1986. Starting from January 1986, parental leave was expanded from 6 to 10 months and all mothers became entitled to maternity payment regardless of their employment status prior to child birth (Dustmann and Schönberg, 2011). Families who had a child in 1986 - being entitled to longer parental leave - are expected, certeris paribus, to increase old-age savings compared to mothers who had a child shortly before the policy change - being entitled to the shorter parental leave.

This institutional feature allows us to apply the same identification strategy, used in this paper. Mothers who had a child in 1986 - being affected by the parental leave expansion - are selected into a treatment group. Whereas families who had a child in 1985 - not affected by the parental leave expansion - are selected into a control group. The parental leave sample mimics the sample that is used in the main part of the paper: It relies on West German couple families with a newborn in 1985 or 1986, while families with multiple births in 1985 or 1986 are excluded. In addition, families in which at least one of the parents is a self-employed farmer, a freelancer, a civil servant or already retired are removed from the sample. The final sample consists of 2,778 families.

Naturally, this identification strategy is only valid if parents in the treatment and the control group are in fact not systematically different. I check this by comparing observable characteristics across both groups based on the EVS 1998, 2003, and 2008 ${ }^{21}$ Table 8 shows the mean comparison of the sample characteristics across treatment and control groups. First, the savings rate based on net income is slightly but not statistically significant higher in the treatment group. Savings relative to gross income is about $10 \%$ in both groups and net wealth is about $€ 220,000$. Parents are statistically significant older in the control group. This is not surprising since children in the

\footnotetext{
${ }^{21}$ Comparing births in 1985 and 1986 based on this data makes it more likely that some children are no longer living in the same household. However, this does not affect the identification since children leaving the household identically affects the treatment and control groups.
} 
control group are on average one year older at the time of the interview. However, it is important to control for the parent's age in the regression analysis. The parent's employment status and share of parents holding a university degree does not differ between the treatment and the control groups. Finally, all families have on average two children at the time of the interview. To sum up, the comparison of the sample characteristics across the treatment and the control groups suggests that both groups are relatively similar.

Table 8: Sample characteristics by treatment and control groups (Analysis of the Parental Leave Reform 1986)

\begin{tabular}{lccccc} 
& Control group & \multicolumn{2}{c}{ Treatment group } & Difference \\
\hline Variable & Mean & SD & Mean & SD & t-statistic \\
\hline Savings and net wealth & & & & & \\
Savings/net income & 0.125 & 0.161 & 0.133 & 0.156 & -1.501 \\
Savings/gross income & 0.100 & 0.129 & 0.105 & 0.124 & -1.215 \\
Net wealth & 224.8 & 255.8 & 215.1 & 226.2 & 1.246 \\
Socio-demographics & & & & & \\
Father's age & 47.16 & 6.545 & 46.40 & 6.667 & $3.534^{* * *}$ \\
Mother's age & 44.00 & 5.534 & 43.23 & 5.640 & $4.228^{* * *}$ \\
Father employed & 0.924 & 0.265 & 0.928 & 0.259 & -0.413 \\
Mother employed & 0.487 & 0.500 & 0.510 & 0.500 & -1.397 \\
University degree (father) & 0.322 & 0.467 & 0.325 & 0.468 & -0.172 \\
University degree (mother) & 0.140 & 0.347 & 0.149 & 0.356 & -0.746 \\
Family size & 4.125 & 0.719 & 4.164 & 0.689 & $-1.718^{*}$ \\
\hline Group size & 1685 & & 2167 & \\
\hline
\end{tabular}

Notes: The sample is based on West German couple families who had a child in 1985 (control group) or in 1986 (treatment group). Net wealth is measured in $€ 100,000$ s. */**/*** Statistically significant at the $10 \% / 5 \% / 1 \%$-level.

Data source: Income and Expenditure Survey (EVS) 1998, 2003, and 2008.

Next, we focus on the results from the estimations depicted in Table 9. The first row contains the estimated impact of being in the treatment group on old-age savings. While in the base model, the treatment effect is captured by a single indicator, the interaction model allows for a differential treatment effect in the three different waves. When we do not include controls, the treatment impact is positive and weakly statistically significant. After including controls, however, being in the treatment group does 
Table 9: Estimation results - Couples (Analysis of the Parental Leave Reform 1986)

\begin{tabular}{lcccc}
\hline & \multicolumn{2}{c}{ Base } & \multicolumn{2}{c}{ Interaction } \\
\hline Treat & $0.0087^{*}$ & 0.0062 & $0.0117^{*}$ & 0.0089 \\
& $(0.0050)$ & $(0.0051)$ & $(0.0069)$ & $(0.0070)$ \\
Treat*2003 & & & -0.0037 & -0.0037 \\
& & & $(0.0110)$ & $(0.0109)$ \\
Treat*2008 & & & -0.0143 & -0.0120 \\
& & & $(0.0161)$ & $(0.0160)$ \\
2003 & $-0.0152^{* * *}$ & -0.0100 & -0.0132 & -0.0080 \\
& $(0.0054)$ & $(0.0062)$ & $(0.0084)$ & $(0.0089)$ \\
2008 & $-0.0161^{* *}$ & 0.0029 & -0.0073 & 0.0103 \\
& $(0.0077)$ & $(0.0098)$ & $(0.0129)$ & $(0.0145)$ \\
\hline Controls & No & Yes & No & Yes \\
\hline N & 3850 & 3850 & 3850 & 3850 \\
\hline
\end{tabular}

Notes: The sample is based on West German couple families who had a child in 1985 (control group) or in 1986 (treatment group). The control variables are the parent's age, education and the father's age and birth order of the child. The specifications that include control variables also control non-parametrically for the age of the mother. All specifications include a constant. Net wealth is measured in $€ 100,000$ s. * $/ * * / * * *$ Statistically significant at the $10 \% / 5 \% / 1 \%$-level, robust standard errors are reported in brackets.

Data source: Income and Expenditure Survey (EVS) 1998, 2003, and 2008 .

not affect family savings. To conclude, this analysis provides evidence that parents tend not to respond to an increase of parental leave by higher old-age savings. 


\subsubsection{Bandwidth variation}

In order to test whether the empirical findings are sensitive to how the bandwidth around the reform cut-off date 1/1/1992 is defined, this section increases the sample and repeats the estimation. So far a family entered the treatment group if it had a child in 1992, hence benefiting from the longer duration of the child care pension benefit. Families who had a child in 1991 - being subject to the shorter child care pension benefit duration - are in the control group. While it is well known that a larger sample increases efficiency, comparing parents who had a child further away from the cut-off date of the reform $(1 / 1 / 1992)$ is less desirable. Those families are more likely to differ in more dimensions than in the child care pension benefit scheme. Nevertheless, for the purpose of this sensitivity check a range of two years is chosen. Now families who had a child in 1990 or 1991 are in the control group, while families who had a child in 1992 or 1993 are in the treatment group. Table 16 in the appendix provides a comparison of the observable characteristics across the two groups. The descriptive comparison does not provide evidence for a systematic difference across treatment and control groups, apart from parents in the control group being on average older and possessing higher levels of net wealth. Table 10 provides the estimated impact of the more generous child care pension benefit on family old-age savings for two scenarios relying on the interaction model, including control variables (equation 2). Comparing the estimated treatment effect from the larger bandwidth to the baseline scenario shows that both models lead to almost identical results even though the sample is nearly twice as large. As in the baseline model, the estimated savings responses are not statistically significant different from zero. 
Table 10: Savings reaction of couple families to the increase of the child care pension benefit after re-defining the treatment and control groups

\begin{tabular}{lccc}
\hline Outcome & Savings/net income & Savings/gross income & Net wealth \\
\hline Baseline scenario & & & \\
Treat & -0.0083 & -0.0096 & 0.3357 \\
& $(0.0053)$ & $(0.0066)$ & $(5.5976)$ \\
Treat*2003 & 0.0128 & 0.0125 & -9.7316 \\
& $(0.0079)$ & $(0.0098)$ & $(12.4216)$ \\
Treat*2008 & 0.0090 & 0.0103 & -8.6956 \\
& $(0.0087)$ & $(0.0109)$ & $(12.5004)$ \\
N & 5450 & 5450 & 5450 \\
Larger bandwidth & & & \\
Treat & -0.0086 & -0.0062 & 6.9111 \\
& $(0.0055)$ & $(0.0045)$ & $(4.9251)$ \\
Treat*2003 & 0.0111 & 0.0091 & -14.7462 \\
& $(0.0082)$ & $(0.0066)$ & $(14.6564)$ \\
Treat*2008 & 0.0125 & 0.0104 & -4.9221 \\
N & $(0.0091)$ & $(0.0073)$ & $(10.5878)$ \\
& 7985 & 7985 & 7985 \\
\hline
\end{tabular}

Notes: The Baseline scenario sample is based on West German couple families who had one child, either in 1991 (control group) or in 1992 (treatment group). The 'larger bandwidth' scenario sample is based on West German couple families who had one child, either in 1990/1991 (control group) or in 1992/1993 (treatment group). */**/*** statistically significant at the 10\%/5\%/1\%-level, robust standard errors are reported in brackets. All specifications contain the following control variables: The parent's education, the father's age, family size, federal states and the quarter of interview. In addition, the specifications control non-parametrically for the age of a mother. All specifications include a constant. Data source: Income and Expenditure Survey (EVS) 1998, 2003, and 2008. 


\section{Discussion and conclusion}

This paper investigates whether a mother's pension wealth crowds-out private savings of families. To identify causal effects I exploit variation in pension wealth given by two extensions of the German child care pension benefit in 1992 and in 1999 using a regression discontinuity design. Child care pension benefits generally increase a mother's pension entitlements in periods when child care precludes work.

The empirical results show that neither old-age savings nor net wealth of couple families that benefited from the more generous child care pension benefit is affected. The analysis of subgroups along the family net wealth or net income quartiles confirms the general findings. The savings response in the first quartile is not substantially different from the one of families in the top quartile. In contrast to couple families, where the relative importance of a mother's pension wealth is lower, single mothers are potentially more prone to be affected by the reforms of the child care pension benefit. However, when analyzing the savings response to the reforms of the child care pension benefit of single mothers, the findings are line with those for couple families. The higher pension wealth does equally not induce single mothers to adjust old-age savings.

The main goal of child care pension benefits is to compensate mothers for child-raising periods that preclude employment. The empirical findings provide evidence that child care pension benefits indeed increase pension wealth without crowding-out private oldage savings. Hence, the child care pension benefit compensates mothers for employment interruptions due to child-raising periods and hence improve the individual old-age income of mothers. A recent pension reform in 2014 increased the pension entitlements - through the child care pension benefit - that are granted to mothers for child births prior to 1992 from one to two years. Based on the findings of this paper, the new so called 'mother's pension' is unlikely to affect old-age savings of mothers.

Finally, old-age income of mothers can be affected in different ways. While the pension benefits do not only provide savings incentives, also the employment and retirement entry decision of mothers might be affected. In Thiemann (2015) I show that mothers do not reduce their employment in response to the longer provision of child care pension benefits. However, it is still an empirical question as to what way child care pension benefits influence the retirement date of mothers. 


\section{References}

Alessie, R., V. Angelini, and P. van Santen (2013). Pension wealth and household savings in Europe: Evidence from Sharelife. European Economic Review 63, 308328.

Angrist, J. D. and V. Lavy (1999). Using Maimonides' Rule to Estimate the Effect of Class Size on Scholastic Achievement. The Quarterly Journal of Economics 114(2), $533-575$.

Attanasio, O. P. and A. Brugiavini (2003). Social security and Households' Saving. Quarterly Journal of Economics 118(3), 1075-1119.

Attanasio, O. P. and S. Rohwedder (2003). Pension wealth and household saving: Evidence from pension reforms in the United Kingdom. American Economic Review 93(5), 1499-1521.

Black, S. E. (1999, May). Do Better Schools Matter? Parental Valuation of Elementary Education. The Quarterly Journal of Economics 114(2), 577-599.

BMAS (2015). Rentenversicherungsbericht. Bundesministerium für Arbeit und Soziales.

Bottazzi, R., T. Jappelli, and M. Padula (2006). Retirement expectations, pension reforms, and their impact on private wealth accumulation. Journal of Public Economics $90(12), 2187-2212$.

Chevalier, A. and M. Olivier (2015). Economic Uncertainty, Parental Selection, and Children's Educational Outcomes. Journal of Political Economy. forthcoming.

Duschek, K.-J. and A. Lemmer (2013, March). Ergebnisse der Sozialhilfestatistik 2011. Statistisches Bundesamt, Wirtschaft und Statistik.

Dustmann, C. and U. Schönberg (2011, September). Expansions in Maternity Leave Coverage and Children's Long-Term Outcomes. American Economic Journal: Applied Economics 4(3), 190-224.

Dustmann, C. and U. Schönberg (2008). The effect of expansions in maternity leave coverage on children's long-term outcomes. IZA Discussion Paper Series 3605.

Ekberg, J., R. Eriksson, and G. Friebel (2013). Parental leave. A policy evaluation of the Swedish Daddy-Month reform. Journal of Public Economics 97(0), 131 - 143. 
Feldstein, M. (1974). Social Security, Induced Retirement, and Aggregate Capital Accumulation. The Journal of Political Economy 82(5), 905-926.

Feldstein, M. and J. Liebman (2002). Handbook of Public Economics, Chapter Chapter 32 - Social Security, pp. 2245-2324. Elsevier Science B.V.

Feldstein, M. and A. Pellechio (1979). Social Security and Household Wealth Accumulation: New Microeconometric Evidence. The Review of Economics and Statistics 61(3), 361-368.

Gale, W. G. (1998). The Effects of Pensions on Household Wealth: A Reevaluation of Theory and Evidence. Journal of Political Economy 106(4), 706-723.

Gans, J. S. and A. Leigh (2009). Born on the first of July: An (un)natural experiment in birth timing. Journal of Public Economics 93, 246-263.

Geisler, E. and M. Kreyenfeld (2005). Müttererwerbstätigkeit in Ost- und Westdeutschland. Eine Analyse mit den Mikrozensen 1991-2002. In Beitrag zur 4. Nutzerkonferenz "Forschung mit dem Mikrozensus: Analysen zur Sozialstruktur und zum Arbeitsmarkt", 12.-13. Oktober 2005, ZUMA, Mannheim.

Hubbard, R. G. (1986). Pension Wealth and Individual Saving: Some New Evidence. Journal of Money, Credit and Banking 18(2), 167-178.

Japelli, T. (1995). Does social security reduce the accumulation of private wealth? Evidence from Italian survey data. Ricerche Economiche 49, 1-31.

King, M. and L.-D. L. Dicks-Mireaux (1982). Asset Holdings and the Life Cycle. The Economic Journal 92, 247-267.

Lachowska, M. and M. Myck (2015). The Effect of Public Pension Wealth on Saving and Expenditure. IZA Discussion Paper Series 8895.

Lee, D. S. and T. Lemieux (2010, September). Regression Discontinuity Designs in Economics. Journal of Economic Literature 48(2), 281-355.

Neugart, M. and H. Ohlsson (2013). Economic incentives and the timing of births: Evidence from the German parental leave reform of 2007. Journal of Population Economics 26, 87-108.

OECD (2013). Pensions at a Glance 2013: OECD and G20 Indicators. OECD Publishing. 
OECD (2015). Pensions at a Glance 2015: OECD and G20 Indicators. OECD Publishing.

Schmähl, W., H. Rothgang, and H. Viebrok (2006). Berücksichtigung von familienleistungen in der alterssicherung analyse und folgerungen aus ökonomischer sicht. DRV Schriften Sonderausgabe der DRV, herausgegeben von Deutsche Rentenversicherung Bund. 65.

Schönberg, U. and J. Ludsteck (2014). Expansions in Maternity Leave Coverage and Mothers' Labor Market Outcomes after Childbirth. Journal of Labor Economics 32(3), 469-505.

Statistisches Bundesamt (2002). Wirtschaftsrechnungen. Aufgabe, Methode und Durchführung 1998, Fachserie 15 Heft 7.

Statistisches Bundesamt (2005). Wirtschaftsrechnungen. Einkommens- und Verbrauchsstichprobe - Aufgabe, Methode und Durchführung der EVS 2003. Fachserie 15 Heft 7.

Statistisches Bundesamt (2013). Wirtschaftsrechnungen. Einkommens- und Verbrauchsstichprobe 2008. Aufgabe, Methode und Durchführung. Fachserie 15 Heft 7.

Tamm, M. (2012). The Impact of a Large Parental Leave Benefit Reform on the Timing of Birth around the Day of Implementation. Oxford Bulletin of Economics and Statistics.

Thiemann, A. (2015). Pension Wealth and Maternal Employment: Evidence from a Reform of the German Child Care Pension Benefit. DIW Discussion Papers 1499.

Thistlethwaite, D. L. and D. T. Campbell (1960, Dec). Regression-discontinuity analysis: An alternative to the ex post facto experiment. Journal of Educational Psychology 51(6), 309-317.

Wagner, G. G., J. R. Frick, and J. Schupp (2007). The German Socio-Economic Panel Study (SOEP) - Evolution, Scope and Enhancements. Schmollers Jahrbuch 127(1), $139-170$. 


\section{Appendix}

Figure 1: Average net wealth by the age of mothers (couple family sample)

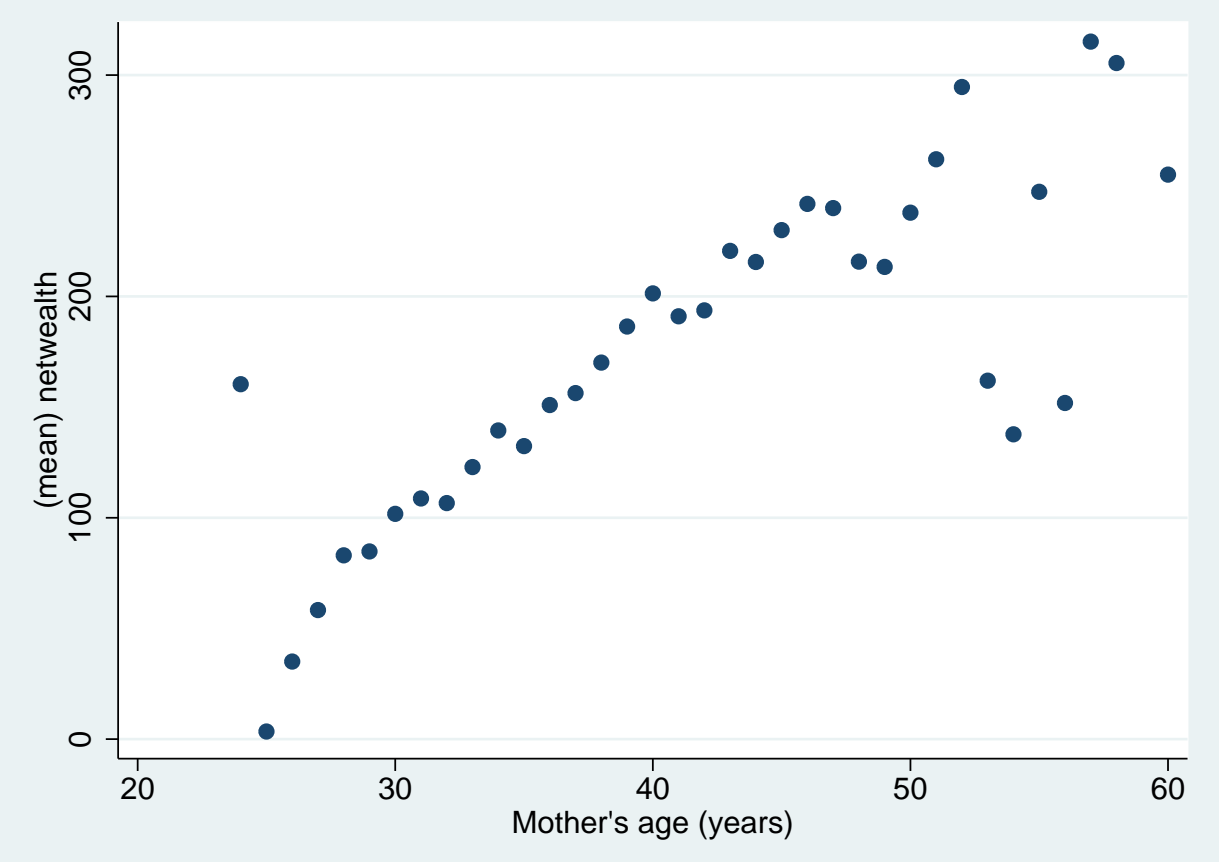

Data source: Income and Expenditure Survey (EVS), own calculation. 
Figure 2: Average net wealth by the age of fathers (couple family sample)

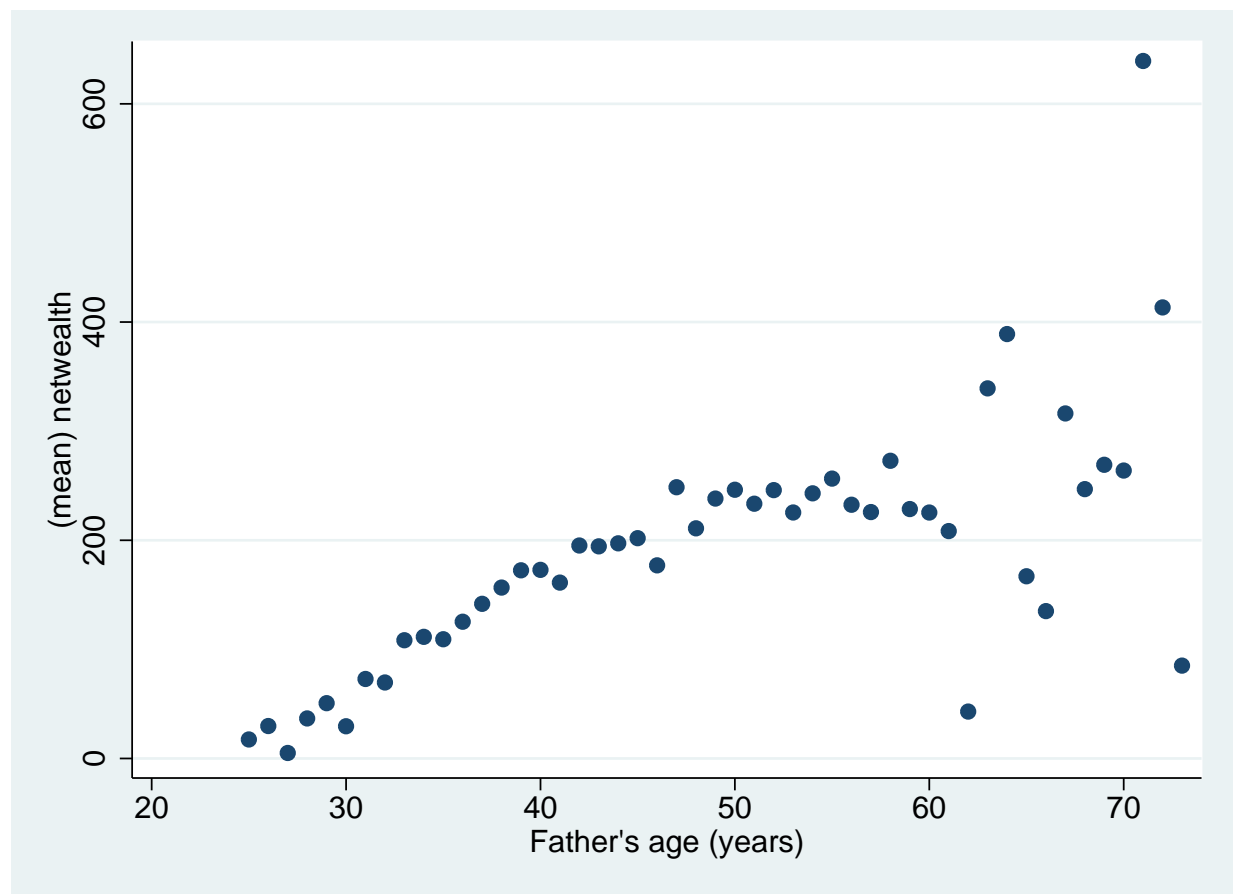

Data source: Income and Expenditure Survey (EVS), own calculation. 
Table 11: The savings reaction of couple families to the increase of child care pension benefits, including detailed estimation results

\begin{tabular}{|c|c|c|c|c|c|c|c|c|}
\hline \multirow{2}{*}{$\begin{array}{l}\text { Outcome } \\
\text { Treat }\end{array}$} & \multicolumn{4}{|c|}{ Savings/gross income } & \multicolumn{4}{|c|}{ Savings/net income } \\
\hline & -0.0022 & -0.0022 & $-0.0092^{*}$ & -0.0083 & -0.0028 & -0.0033 & -0.0099 & -0.0096 \\
\hline Treat*2003 & & & $0.0148^{*}$ & 0.0128 & & & 0.0141 & 0.0125 \\
\hline Treat*2008 & & & 0.0105 & 0.0090 & & & 0.0119 & 0.0103 \\
\hline 2003 & $-0.0122^{* * *}$ & $-0.0130^{* * *}$ & $-0.0194^{* * *}$ & $-0.0193^{* * *}$ & $-0.0130 * * *$ & $-0.0145^{* *}$ & $-0.0199 * * *$ & $-0.0206^{* * *}$ \\
\hline 2008 & $-0.0272^{* * *}$ & $-0.0242^{* * *}$ & $-0.0325^{* * *}$ & $-0.0288^{* * *}$ & $-0.0305^{* * *}$ & $-0.0277^{* * *}$ & $-0.0364^{* * *}$ & $-0.0330^{* * *}$ \\
\hline Father age & & 0.0001 & & 0.0001 & & -0.0000 & & -0.0000 \\
\hline Househ. size & & 0.0036 & & 0.0035 & & -0.0004 & & -0.0004 \\
\hline Father empl. & & $0.0246^{* * *}$ & & $0.0248^{* * *}$ & & $0.0424^{* * *}$ & & $0.0426^{* * *}$ \\
\hline Mother empl. & & $0.0128^{* * *}$ & & $0.0128^{* * *}$ & & $0.0233^{* * *}$ & & $0.0233^{* * *}$ \\
\hline Mother educ.2 & & $-0.0161^{*}$ & & $-0.0160^{*}$ & & -0.0176 & & -0.0175 \\
\hline Mother educ.3 & & $-0.0151^{*}$ & & $-0.0150^{*}$ & & $-0.0186^{*}$ & & $-0.0185^{*}$ \\
\hline Mother educ. 4 & & -0.0100 & & -0.0099 & & -0.0127 & & -0.0127 \\
\hline Mother educ. 5 & & -0.0071 & & -0.0072 & & -0.0074 & & -0.0075 \\
\hline Mother educ. 6 & & -0.0201 & & -0.0195 & & -0.0288 & & -0.0282 \\
\hline Mother educ.7 & & -0.0034 & & -0.0034 & & -0.0045 & & -0.0045 \\
\hline Father educ.2 & & 0.0044 & & 0.0044 & & 0.0017 & & 0.0017 \\
\hline Father educ.3 & & -0.0028 & & -0.0028 & & -0.0035 & & -0.0035 \\
\hline Father educ.4 & & -0.0096 & & -0.0095 & & $-0.0124^{*}$ & & $-0.0123^{*}$ \\
\hline Father educ.5 & & -0.0206 & & -0.0204 & & -0.0230 & & -0.0227 \\
\hline Father educ.6 & & $-0.0723^{*}$ & & $-0.0716^{*}$ & & $-0.0769^{*}$ & & $-0.0762^{*}$ \\
\hline Father educ.7 & & $-0.0274^{*}$ & & $-0.0275^{* *}$ & & $-0.0361^{* *}$ & & $-0.0363^{* *}$ \\
\hline Intv. 2. quart. & & -0.0043 & & -0.0043 & & -0.0048 & & -0.0048 \\
\hline Intv. 3. quart. & & $-0.0154^{* * *}$ & & $-0.0154^{* * *}$ & & $-0.0184^{* * *}$ & & $-0.0184^{* * *}$ \\
\hline Intv. 4. quart. & & 0.0013 & & 0.0014 & & 0.0056 & & 0.0058 \\
\hline Constant & $0.1149^{* * *}$ & $0.1929^{* * *}$ & $0.1185^{* * *}$ & $0.1967^{* * *}$ & $0.1435^{* * *}$ & $0.2510^{* * *}$ & $0.1472^{* * *}$ & $0.2548^{* * *}$ \\
\hline Federal states & No & Yes & No & Yes & No & Yes & No & Yes \\
\hline Mage dummies & No & Yes & No & Yes & No & Yes & No & Yes \\
\hline $\mathrm{N}$ & 5450 & 5450 & 5450 & 5450 & 5450 & 5450 & 5450 & 5450 \\
\hline
\end{tabular}

Notes: The sample is based on West German couple families who had a child either in 1991 (control group) or in 1992 (treatment group). The specifications that include control variables also control non-parametrically for the age of the mother. The education variable definition is as follows: 1 (reference category) - 'university degree', 2 'technical college degree', 3 'senior clerk, technician, master craftsman', 4 'apprenticeship', 5 'other professional qualification', 6 'undergoing training', 7 'no degree'. */**/*** Statistically significant at the $10 \% / 5 \% / 1 \%$-level.

Data source: Income and Expenditure Survey (EVS) 1998, 2003, and 2008. 
Table 12: The impact of the increase in child care pension benefits on net wealth of couple families

\begin{tabular}{|c|c|c|c|c|}
\hline \multirow{2}{*}{$\begin{array}{l}\text { Outcome } \\
\text { Treat }\end{array}$} & \multicolumn{4}{|c|}{ Net wealth } \\
\hline & $-15.0857^{* * *}$ & -4.7010 & $-15.0017^{* *}$ & 0.3357 \\
\hline Treat*2003 & & & -1.7503 & -9.7316 \\
\hline Treat*2008 & & & 2.0994 & -8.6956 \\
\hline 2003 & $43.6087^{* * *}$ & -5.6541 & $44.4512^{* * *}$ & -0.8899 \\
\hline 2008 & $41.0248^{* * *}$ & $-48.8457^{* * *}$ & $40.0106^{* * *}$ & $-44.4733^{* * *}$ \\
\hline Father age & & $5.3760^{* * *}$ & & $5.3876^{* * *}$ \\
\hline Househ. size & & $17.1118^{* * *}$ & & $17.1449^{* * *}$ \\
\hline Father empl. & & $50.9554^{* * *}$ & & $50.7912^{* * *}$ \\
\hline Mother empl. & & -6.3302 & & -6.3078 \\
\hline Mother educ.2 & & -8.2410 & & -8.3330 \\
\hline Mother educ.3 & & -10.6023 & & -10.7010 \\
\hline Mother educ.4 & & -13.0487 & & -13.0744 \\
\hline Mother educ.5 & & $-65.6898^{* * *}$ & & $-65.5971^{* * *}$ \\
\hline Mother educ. 6 & & $-66.9386^{* * *}$ & & $-67.4251^{* * *}$ \\
\hline Mother educ.7 & & $-59.2426^{* * *}$ & & $-59.3070^{* * *}$ \\
\hline Father educ.2 & & $18.4387^{*}$ & & $18.4020^{*}$ \\
\hline Father educ.3 & & -2.0676 & & -2.0847 \\
\hline Father educ.4 & & $-35.4073^{* * *}$ & & $-35.4920^{* * *}$ \\
\hline Father educ.5 & & $-61.3964^{* * *}$ & & $-61.6282^{* * *}$ \\
\hline Father educ.6 & & 6.6691 & & 6.1077 \\
\hline Father educ.7 & & $-71.1146^{* * *}$ & & $-71.0262^{* * *}$ \\
\hline Intv. 2. quart. & & 9.2895 & & 9.2952 \\
\hline Intv. 3. quart. & & 6.6170 & & 6.6407 \\
\hline Intv. 4. quart. & & -6.7401 & & -6.8820 \\
\hline Constant & $163.1210^{* * *}$ & -95.7238 & $163.0784^{* * *}$ & -98.8131 \\
\hline Federal states & No & Yes & No & Yes \\
\hline Mage dummies & No & Yes & No & Yes \\
\hline $\mathrm{N}$ & 5450 & 5450 & 5450 & 5450 \\
\hline
\end{tabular}

Notes: The sample is based on West German couple families who had a child either in 1991 (control group) or in 1992 (treatment group). The specifications that include control variables also control non-parametrically for the age of the mother. The education variable definition is as follows: 1 (reference category) - 'university degree', 2 'technical college degree', 3 'senior clerk, technician, master craftsman', 4 'apprenticeship', 5 'other professional qualification', 6 'undergoing training', 7 'no degree'. */**/*** Statistically significant at the $10 \% / 5 \% / 1 \%$-level.

Data source: Income and Expenditure Survey (EVS) 1998, 2003, and 2008. 


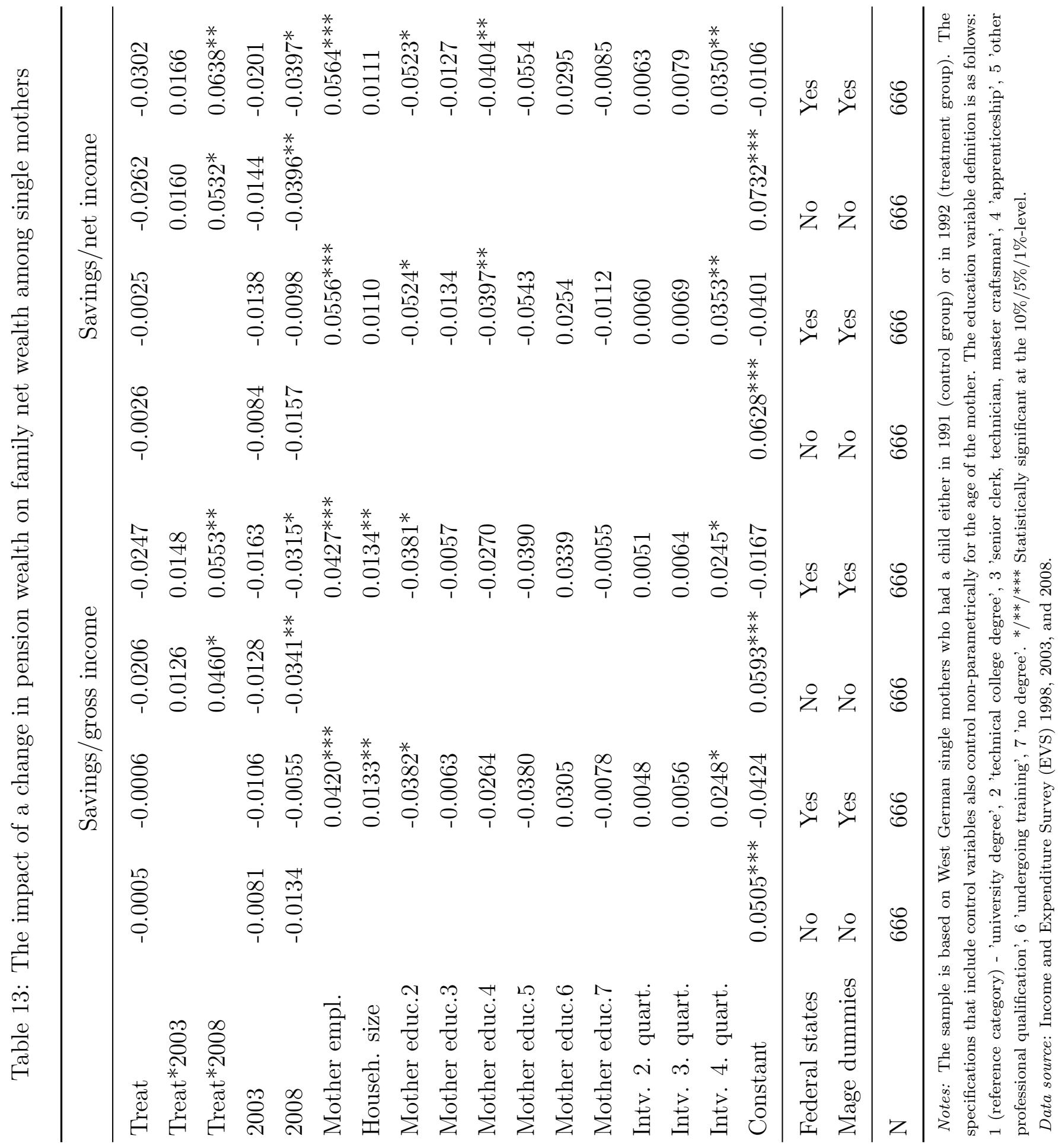


Table 14: The impact of pension wealth on family savings among single mothers

\begin{tabular}{|c|c|c|c|c|}
\hline \multirow{2}{*}{$\frac{\text { Outcome }}{\text { Treat }}$} & \multicolumn{4}{|c|}{ Net wealth } \\
\hline & -1.7760 & 0.4547 & -5.0505 & -2.6365 \\
\hline Treat*2003 & & & 7.5054 & 0.8109 \\
\hline Treat*2008 & & & 2.4009 & 8.0960 \\
\hline 2003 & 8.2954 & -6.1484 & 4.5009 & -6.2972 \\
\hline 2008 & 6.6152 & $-23.4751^{*}$ & 5.5824 & -27.3215 \\
\hline Mother empl. & & $31.1840^{* * *}$ & & $31.3159^{* * *}$ \\
\hline Househ. size & & $13.1172^{* * *}$ & & $13.1297^{* * *}$ \\
\hline Mother educ.2 & & -12.2846 & & -12.3113 \\
\hline Mother educ.3 & & $-40.5360^{* *}$ & & $-40.4278^{* *}$ \\
\hline Mother educ.4 & & -23.3316 & & -23.4347 \\
\hline Mother educ.5 & & $-84.8053^{* * *}$ & & $-85.0711^{* * *}$ \\
\hline Mother educ.6 & & $-64.9544^{* * *}$ & & $-64.2682^{* * *}$ \\
\hline Mother educ.7 & & $-46.3695^{* *}$ & & $-45.9146^{* *}$ \\
\hline Intv. 2. quart. & & 14.1485 & & 14.2405 \\
\hline Intv. 3. quart. & & 5.1937 & & 5.3498 \\
\hline Intv. 4. quart. & & 7.5688 & & 7.5363 \\
\hline Constant & $49.4397^{* * *}$ & 19.5437 & $50.8751^{* * *}$ & 22.7747 \\
\hline Federal states & No & Yes & No & Yes \\
\hline Mage dummies & No & Yes & No & Yes \\
\hline $\mathrm{N}$ & 666 & 666 & 666 & 666 \\
\hline
\end{tabular}

Notes: The sample is based on West German single mothers who had a child either in 1991 (control group) or in 1992 (treatment group). The specifications that include control variables also control non-parametrically for the age of the mother. The education variable definition is as follows: 1 (reference category) - 'university degree', 2 'technical college degree', 3 'senior clerk, technician, master craftsman', 4 'apprenticeship', 5 'other professional qualification', 6 'undergoing training', 7 'no degree'. */**/*** Statistically significant at the $10 \% / 5 \% / 1 \%$ level.

Data source: Income and Expenditure Survey (EVS) 1998, 2003, and 2008. 
Table 15: Sample characteristics by treatment- and control groups (single mothers)

\begin{tabular}{lccccc} 
& \multicolumn{2}{c}{ Control group } & \multicolumn{2}{c}{ Treatment group } & Difference \\
\hline Variable & Mean & SD & Mean & SD & t-statistic \\
\hline Savings and net wealth & & & & & \\
Savings/gross income & 0.043 & 0.131 & 0.043 & 0.126 & 0.085 \\
Savings/net income & 0.055 & 0.160 & 0.052 & 0.145 & 0.243 \\
Net wealth & 54.15 & 107.0 & 52.94 & 106.3 & 0.146 \\
Socio-demographics & & & & & \\
Mother's age & 41.03 & 6.07 & 41.22 & 5.83 & -0.419 \\
University degree & 0.187 & 0.390 & 0.198 & 0.399 & -0.377 \\
Mother employed & 0.746 & 0.436 & 0.672 & 0.470 & $2.122^{* *}$ \\
Family size & 2.813 & 0.838 & 2.885 & 0.847 & -1.103 \\
\hline Group size & \multirow{2}{*}{343} & & 323 & \\
\hline
\end{tabular}

Notes: The sample is based on West German single mothers who had a child either in 1991 (Control group) or in 1992 (Treatment group). */***** Statistically significant at the $10 \% / 5 \% / 1 \%$-level.

Data source: Income and Expenditure Survey (EVS) 1998, 2003, and 2008. 
Table 16: Sample characteristics by treatment- and control groups (larger bandwidth)

\begin{tabular}{lccccc} 
& \multicolumn{2}{c}{ Control } & Treatment & Difference \\
\hline Variable & Mean & SD & Mean & SD & t-statistic \\
\hline Savings/wealth & & & & & \\
Savings/gross income & 0.103 & 0.128 & 0.104 & 0.126 & -0.157 \\
Savings/net income & 0.132 & 0.159 & 0.131 & 0.157 & 0.110 \\
Net wealth & 189.5 & 319.6 & 167.2 & 178.5 & $3.856^{* * *}$ \\
Socio-demographics & & & & & \\
Mother's age & 40.85 & 5.774 & 38.86 & 5.762 & $15.39^{* * * *}$ \\
Father's age & 43.81 & 6.538 & 41.64 & 6.702 & $14.63^{* * *}$ \\
Mother employed & 0.476 & 0.499 & 0.489 & 0.500 & -1.121 \\
Father employed & 0.941 & 0.235 & 0.939 & 0.240 & 0.431 \\
University degree (mother) & 0.157 & 0.364 & 0.163 & 0.370 & -0.702 \\
University degree (father) & 0.324 & 0.468 & 0.328 & 0.469 & -0.284 \\
Family size & 4.111 & 0.670 & 4.118 & 0.658 & -0.462 \\
\hline Group size & 3977 & 4008 & \\
\hline
\end{tabular}

Notes: The sample is based on West German couple families who had a child either in 1990/1991 (Control group) or in 1992/1993 (Treatment group). */**/*** Statistically significant at the $10 \% / 5 \% / 1 \%$-level.

Data source: Income and Expenditure Survey (EVS) 1998, 2003, and 2008. 